\title{
PERAN KARAKTERISTIK, PENGETAHUAN DAN SIKAP PEKERJA TERHADAP PRAKTIK PENGELOLAAN LIMBAH DI INSTALASI KARANTINA HEWAN (Characteristics, Knowledge and Attitude of Workers Regarding Waste Management Practices in Animal Quarantine Installations)
}

\author{
Nuryani Zainuddin ${ }^{1 *}$, Mohamad Samsul Maarif ${ }^{2}$, Etty Riani $^{3}$, dan Susan Maphilindawati \\ Noor $^{4}$ \\ ${ }^{1}$ Departemen Pengelolaan Sumberdaya Alam dan Lingkungan, Institut Pertanian Bogor, \\ Jl. Agatis, Kampus IPB Darmaga Bogor 16680. \\ ${ }^{2}$ Sekolah Bisnis, Institut Pertanian Bogor, Kampus IPB Gunung Gede, \\ Jl. Raya Pajajaran, Bogor, 16128. \\ ${ }^{3}$ Departemen Departemen Pemanfaatan Sumberdaya Perikanan, Fakultas Perikanan dan Kelautan, \\ Institut Pertanian Bogor, Jl. Agatis, Kampus IPB Darmaga Bogor . \\ ${ }^{4}$ Balai Besar Penelitian Veteriner, Kementerian Pertanian, \\ Jl. RE. Martadinata No. 30, Kotak Pos 151, Bogor 16114.
}

*Penulis korespondensi. Tel: 0251-8425503. Email: nuryanizainuddin@yahoo.com.

Diterima: 11 November 2018

Disetujui: 15 September 2019

\begin{abstract}
Abstrak
Limbah Instalasi Karantina Hewan (IKH) ruminansia besar dapat menjadi sumber penularan penyakit yang mungkin terbawa akibat lalu lintas ternak serta dapat menimbulkan permasalahan lingkungan. Tujuan penelitian ini untuk menganalisis sejauh mana karakteristik, pengetahuan dan sikap petugas IKH berpengaruh terhadap praktik pengelolaan limbah di IKH. Responden adalah petugas yang melakukan pengelolaan limbah di IKH. Hubungan dan tingkat pengaruh langsung dan tidak langsung pada variabel yang diamati dianalisis menggunakan analisis jalur (path analysis). Hasil penelitian menunjukkan secara keseluruhan karakteristik, pengetahuan dan sikap petugas IKH berpengaruh sebesar $68,85 \%$. Pengaruh tersebut digambarkan sebagai pengaruh langsung sebesar $22,76 \%$ dan tidak langsung sebesar $46,09 \%$ terhadap praktik pengelolaan limbah di IKH. Pengetahuan berpengaruh signifikan terhadap sikap dan praktik pengelolaan limbah di IKH. Sikap berpengaruh signifikan terhadap praktik pengelolaan limbah di IKH. Pengelolaan limbah di IKH dapat ditingkatkan dengan cara meningkatkan pengetahuan melalui pelatihan sistem manajemen lingkungan sesuai ISO 14001:2015, pelatihan AMDAL dan UKL/UPL serta pengetahuan mengenai risiko penyakit yang mungkin terbawa oleh limbah IKH.
\end{abstract}

Kata kunci: karantina hewan, limbah, pengelolaan limbah, praktik, sikap.

\begin{abstract}
Waste from large ruminant animal quarantine installations (IKH) can be a source of disease transmission that may be carried away due to livestock traffic and can cause environmental problems. The purpose of this study was to analyze the characteristics, knowledge and attitudes of IKH officers to influence the practice of waste management in IKH. Respondents were officers who carry out waste management in IKH. The relationship and magnitude of direct and indirect effects on observed variables were analyzed using path analysis. The results showed that overall the characteristics, knowledge and attitudes of IKH officers had an effect of 68.85\%. The influence is described as a direct influence of $22.76 \%$ and indirectly by $46.09 \%$ on the practice of waste management in IKH. The practice of waste management in IKH is influenced by significant knowledge and attitudes. Attitudes are influenced by knowledge of waste management in IKH. Waste management in IKH can be improved by increasing knowledge through training in environmental management systems in accordance with ISO 14001: 2015, training on AMDAL and UKL / UPL as well as knowledge about the risk of diseases that may be carried out by IKH waste.
\end{abstract}

Keywords: animal quarantine, attitude, waste management, practice, waste.

\section{PENDAHULUAN}

Peningkatan lalu lintas hewan antar negara, baik dalam rangka perdagangan, pertukaran, maupun penyebarannya, akan membuka peluang potensi masuk dan menyebarnya hama dan penyakit hewan yang berbahaya atau menular, sehingga sangat berpotensi terhadap kesehatan ternak dan manusia serta dapat merusak sumberdaya alam hayati. Terkait hal tersebut, menurut Undang Undang no 16/1992, Badan Karantina Pertanian menjadi pintu terdepan untuk 
mencegah masuk hama penyakit hewan karantina ke wilayah Republik Indonesia, dan mencegah tersebarnya hama penyakit hewan karantina dari suatu area ke area lain di Indonesia, serta mencegah keluarnya hama penyakit tersebut dari wilayah negara Republik Indonesia. Oleh sebab itu maka Badan Karantina Pertanian melakukan penanganan yang cermat, berdasarkan kaidah-kaidah teknis yang diperlukan, agar kegiatan importasi sapi yang berisiko membawa penyakit tidak berdampak pada kesehatan ternak di dalam negeri dan kesehatan masyarakat terhadap penyebaran dan serangan penyakit hewan menular yang bersifat zoonosis.

Tindakan teknis pada kegiatan impor sapi dilakukan pada masa karantina, yakni selama 14 hari atau diperpanjang sampai waktu yang telah ditetapkan, tergantung dari masa pengamatan pasca masuk yang dilaksanakan di dalam Instalasi Karantina Hewan (IKH). IKH adalah suatu bangunan berikut peralatan, lahan serta sarana pendukung yang diperlukan sebagai tempat untuk melakukan tindakan karantina yang harus memenuhi persyaratan teknis, baik bangunan, peralatan kandang, serta sarana dan prasarananya. Media pembawa yang dikenakan tindakan karantina di IKH adalah media pembawa yang memiliki risiko tinggi, memerlukan tindakan karantina yang efektif, memerlukan perlakuan tertentu dan atau memerlukan tindakan karantina lebih lanjut sesuai Peraturan Menteri Pertanian 70/2015. Salah satu media pembawa yang dikenakan masa karantina di IKH adalah ruminansia besar seperti sapi.

IKH berdasarkan kepemilikan dibagi menjadi dua, yaitu IKH pemerintah dan IKH pihak lain. IKH pemerintah adalah IKH yang dikelola dan dibangun dengan dana pemerintah, sedangkan IKH pihak lain adalah IKH yang dibandgun oleh perseorangan atau perusahaan berbadan hukum yang terlebih dahulu dinilai kelayakannya oleh Badan Karantina Pertanian sebelum ditetapkan sebagai IKH. Jumlah IKH ruminansia besar yang dimiliki pemerintah yang ada saat ini sebanyak 23 IKH dan IKH ruminansia besar pihak lain yang masih aktif sebanyak 57 unit IKH, yang semuanya tersebar di seluruh wilayah Indonesia (Anonim, 2017).

Impor sapi memiliki kontribusi yang berharga bagi ekonomi global dan kesejahteraan manusia, tetapi berdampak negatif terhadap lingkungan yang dapat mempengaruhi air, udara, dan tanah. Kotoran hewan merupakan sumber utama yang penting menjadi perhatian. Kekhawatiran lainnya adalah pelepasan gas metan dari fermentasi usus ruminansia, partikulat dari kandang hewan, dan pembuangan ternak yang mati (Scanes, 2018). Hasil penelitian Hutchison dkk. (2004) dapat mengisolasi bakteri Salmonella sp, Listeria sp, dan
Campylobacter spp dan Escherichia coli O:157 pada limbah ternak dengan rata rata $10^{6} / \mathrm{g}$ feses sebelum disebarkan ke tanah. Hutchison dkk., (2004) memperlihatkan bahwa dari 1456 sampel limbah ternak, paling tidak terdapat/sedikitnya ada $50,4 \%$ yang terkontaminasi bakteri pathogen Salmonella sp, Listeria sp, Campylobacter spp dan E. coli O:157.

Limbah IKH ruminansia besar harus dikelola dengan baik agar tidak menjadi sumber penyakit bagi lingkungan di sekitarnya. Berdasarkan penelitian Santoso (2012), terhadap 16 IKH yang terdapat di pulau Jawa, 93,8\% IKH sudah memiliki penampungan limbah kotoran ternak, namun terdapat masih terdapat $6,2 \%$ IKH yang masih membuang limbah kotoran hewan ke parit atau sungai. Keadaan ini sangat berbahaya terhadap lingkungan karena bisa berpotensi menjadi sumber penularan penyakit dan pencemaran lingkungan. Limbah ternak dapat memberikan keuntungan ekonomi bagi pekerja dengan dan tanpa diolah terlebih dahulu. Pemanfaatan limbah IKH tanpa diolah terlebih dahulu akan menyebabkan keluar dan penyebaran mikroorganisme pathogen yang mungkin terbawa oleh ternak yang dalama masa karantina.

Manusia merupakan bagian yang tidak terlepas dari lingkungannya. Lingkungan merupakan alat bagi manusia untuk kelangsungan hidupnya, dengan demikian manusia sangat membutuhkan lingkungannya dan dapat juga menyebabkan kerusakannya. Menurut Keraf (2002), masalah lingkungan hidup adalah masalah moral manusia, kerusakan bukan pada masalah teknis tetapi krisis lingkungan adalah krisis moral manusia, sehingga perlu merubah cara pandang dan perilakunya terhadap lingkungan. Perilaku yang kurang baik dalam menangani limbah IKH dapat menimbulkan akibat buruk, antara lain: penurunan keindahan lingkungan, bau yang tidak sedap, menurunkan kualitas air, tanah, udara, serta dapat menimbulkan gangguan kesehatan.

Salah satu faktor yang menjamin keamanan dan mencegah penyebaran hama penyakit hewan karantina melalui penerapan praktik higiene pada pekerja terhadap pengelolaan limbah di IKH melalui pengelolaan limbah cair, limbah padat dan sisa pakan yang dapat mencemari lingkungan disekitar IKH. Perilaku yang kurang baik dalam menangani limbah IKH dapat menimbulkan akibat buruk, antara lain menurunnya keindahan lingkungan, bau yang tidak sedap, menurunkan kualitas air, tanah, dan udara, serta dapat menimbulkan gangguan kesehatan. Penanganan limbah ternak yang kurang baik ada kaitannya dengan perilaku atau praktik peternak dalam menangani limbah ternaknya (Khoiron, 2012). Pola 
perilaku individu terhadap suatu obyek dipengaruhi oleh faktor sosio demografi seperti umur, pendidikan dan masa kerja, dan faktor sosial ekonomi (Widayati, 2012).

Implementasi penanganan limbah IKH tidak terlepas dari karakteristik, tingkat pengetahuan, sikap, dan praktik dari pekerja yang menangani hal tersebut. Karakteristik yang dimaksud meliputi umur, tingkat pendidikan, masa kerja dan penghasilan. Tingkat pengetahuan petugas di IKH dinilai dari pemahamannya terhadap sumber pencemaran, wujud limbah, jenis limbah, sifat limbah, dampak yang mungkin dihasilkan baik terhadap manusia dan lingkungan di sekitarnya, cara menangani limbah dengan benar, pengolahan limbah, pemanfaatannya, alat pelindung diri, penggunaan teknologi, risiko yang diperolah dari limbah ternak serta saranan dan prasarana pengolahan limbah serta peraturan terkait pengelolaan limbah dari usaha peternakan.

Sementara menurut Samani dan Hariyanto (2012), indikator sikap terhadap pengelolaan limbah di IKH dapat dinilai dari perhatian, kesediaan, adanya daya upaya, menghargai kesehatan dirinya dan masyarakat di sekitarnya, dan bertanggung jawab. Hal tersebut akan muncul apabila didorong oleh pengetahuan yang dimiliki terhadap pengelolaan limbah. Sikap yang timbul dapat terbentuk dari kepercayaan, perasaan, atau penilaian pada praktik pencegahan dan pengendalian yang diikuti dengan kecenderungan berperilaku terhadap pengelolaan limbah IKH. Indikator perilaku dinilai melalui implementasi dari pengetahuan dan sikap petugas. Selain itu perilaku dinilai dari implementasi dari prosedur operasional pengelolaan limbah di IKH itu sendiri. Berdasarkan hal tersebut, tujuan penelitian ini adalah untuk menganalisis hubungan karakteristik, pengetahuan, dan sikap terhadap praktik pengelolaan limbah di IKH.

\section{METODE PENELITIAN}

\section{Waktu dan Lokasi}

Pengambilan data responden dilakukan di 13 IKH pihak lain yang berlokasi di Jawa Barat, Banten dan Lampung, dengan jumlah responden sebanyak 166 orang. Penelitian dilaksanakan selama 5 (lima) bulan yaitu bulan November 2017 sampai dengan Februari 2018.

\section{Prosedur dan Analisa Data}

Penelitian ini menggunakan studi lapang cross sectional dengan menggunakan kuesioner terstruktur sebagai alat untuk mengukur karakteristik, tingkat pengetahuan, sikap dan praktik pengolahan limbah di IKH. Survei ini disebut survey Knowledge, Attitude and Practice (KAP survey) yang dikembangkan oleh Anonim (2008). Survei KAP menggunakan alat bantu penelitian berupa kuisioner terstruktur. Sebelum penelitian dimulai, dilakukan uji pendahuluan, uji konsistensi internal, dan uji reliabilitas pada kuisioner yang akan digunakan. Uji konsistensi internal menggunakan korelasi peringkat Spearman. Uji reliabilitas menggunakan model single trial administration dengan metode konsistensi internal belah dua atau splithalf method (Idrus, 2009).

Sumber data primer adalah dari responden yang ada di IKH. Pengambilan data dilakukan melalui wawancara dan melakukan observasi terhadap responden. Responden adalah para pekerja kandang di IKH baik yang menangani limbah IKH secara langsung dan tidak langsung. Total IKH swasta yang masih aktif digunakan dalam dua tahun terkhir adalah 30 perusahaan. Penentuan besaran sampel dilakukan dengan menggunakan rumus persamaan Slovin (Amirin, 2011) dengan jumlah pekerja yang mengelola limbah sebanyak 285 orang dengan tingkat kepercayaan 95\% maka banyaknya responden yang dibutuhkan sebanyak 166 sampel. Penentuan lokasi pengambilan data responden IKH dilakukan dengan menggunakan sampling acak maka diperoleh 13 lokasi IKH dengan jumlah masing masing responden dari setiap IKH bervariasi antara 11-13 responden.

Praktik pengelolaan limbah di IKH terdiri dari tiga komponen, yaitu komponen sanitasi, fasilitas, dan tata laksana. Komponen sanitasi mencakup penggunaan alat pelindung diri, kebiasaan mencuci tangan dan kebiasaan yang bisa menyebabkan penularan penyakit saat menangani limbah IKH. Komponen fasilitas mencakup sistem saluran limbah, alat ukur pada penampungan limbah, sistem drainase dan teknologi pengelolaan limbah IKH. Komponen tata laksana mencakup pemantauan Upaya Pengelolaan Lingkungan Hidup (UKL) dan Upaya Pemantauan Lingkungan Hidup (UPL) oleh IKH, pengelolaan limbah padat, pengelolaan limbah cair, tindakan terhadap rodensia dan serangga, dan sistem pelaporan monitoring UKL/UPL.

Penggunaan kuisioner terstruktur dengan dilengkapi karakteristik individu pekerja, 19 pertanyaan untuk mengukur tingkat pengetahuan dengan 3 pilihan jawaban yaitu benar, salah dan tidak tahu (Hart dkk. 2007). Jika jawaban benar diberi nilai 2, jika jawaban salah dan tidak tahu diberi nilai 1 (Palaian dkk., 2007). Pengukuran sikap menggunakan 19 pernyataan negatif dengan 4 pilihan jawaban yaitu sangat setuju, setuju, tidak setuju dan sangat tidak setuju. Pada jawaban "sangat setuju" diberi nilai 4 dan "setuju" diberi nilai 3, , untuk jawaban "tidak setuju" diberi nilai 2 
dan sangat tidak setuju" diberi nilai 1. Pengukuran praktik dilakukan melalui skoring pada 19 pertanyaan kunci, pada jawaban "selalu" diberi nilai 3, "kadang kadang" diberi nilai 2 sedangkan "tidak pernah" diberi nilai 1 dan ditambah observasi langsung menggunakan checklist. Data yang diperoleh dianalisis dengan statistika deskriptif dan analisis jalur (path analysis) untuk mengetahui hubungan antar variable baik langsung maupun tidak langsung. Hasil penelitian diharapkan dapat memberikan masukan kepada para pembuat kebijakan mengenai pengelolaan limbah IKH, seperti digambarkan dalam kerangka konsep penelitian (Gambar 1).

Analisis jalur (path analysis) digunakan untuk mengetahui hubungan antar variabel dan besarnya pengaruh langsung dan tidak langsung setiap variabel. Dalam penelitian ini dikembangkan 3 model persamaan regresi dalam analisis jalur dan disajikan pada Tabel 3. Model pertama untuk menilai peran karakteristik yang mempengaruhi pengetahuan tentang pengelolaan limbah IKH. Untuk menilai pengaruh karakteristik dan pengetahuan terhadap sikap petugas pengelolaan limbah di IKH maka dapat dijelaskan dengan model kedua, sedangkan untuk melihat peran karakteristik, pengetahuan dan sikap terhadap praktik pengelolaan limbah di IKH akan dijabarkan pada model ketiga.

Hipotesis dari Model 1 adalah $\mathrm{H} 0=$ Karakteristik tidak mempengaruhi pengetahuan sementara, $\mathrm{H} 1=$ Karakteristik mempengaruhi pengetahuan. Hipotesis dari model 2 yaitu $\mathrm{HO}=$ Karakteristik dan pengetahuan tidak mempengaruhi sikap, sementara H1 = Karakteristik dan pengetahuan mempengaruhi sikap sedangkan hipotesis dari model 3 adalah $\mathrm{H} 0=$ Karakteristik, pengetahuan dan sikap tidak mempengaruhi praktik, sementara $\mathrm{H} 1=$ Karakteristik, pengetahuan dan sikap mempengaruhi praktik.

\section{HASIL DAN PEMBAHASAN}

Karakteristik responden yang diamati sebagai variabel penelitian antara lain umur (X1), Pendidikan (X2), masa kerja (X3), penghasilan (X4). Karaktaristik tersebut akan dihubungkan dengan nilai pengetahuan $(\mathrm{P})$, nilai sikap $(\mathrm{S})$ dan nilai praktik (Y) terhadap pengelolaan limbah di IKH. Umur (X1) dikelompokkan menjadi 4 kelompok yaitu <20, 20-40, 40-60 dan >60 tahun. Tingkat pendidikan adalah pendidikan formal sesuai ijazah terakhir. Untuk tingkat pendapatan perbulan, responden dikelompokkan menjadi empat kelompok yaitu rendah (di bawah 3 juta rupiah), sedang (3-5 juta rupiah), tinggi (5-10 juta rupiah), dan sangat tinggi (di atas 10 juta rupiah). Masa

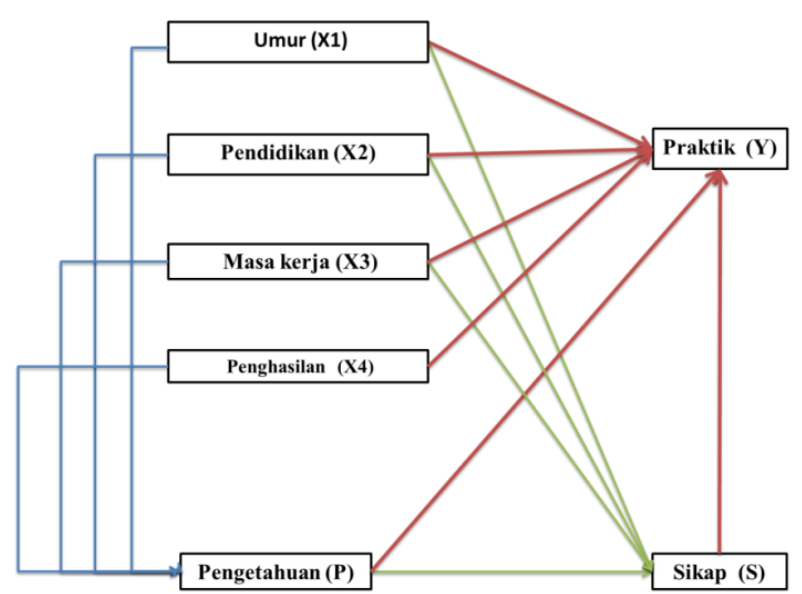

Gambar 1. Kerangka konsep penelitian karakteristik, pengetahuan dan sikap pekerja terhadap praktik pengelolaan limbah di IKH.

kerja responden dikelompokkan menjadi empat kelompok yaitu, kurang dari setahun, antara 1-3 tahun, antara 3-5 tahun dan lebih dari 5 tahun. Selain sebagai pengelola limbah di IKH, responden diketahui memiliki pekerjaan sampingan sebagai pedagang/wiraswasta, tukang ojek, dan lain lain. Pelatihan terhadap pengelolaan limbah terhadap responden dibagi menjadi dua yaitu pernah dan tidak pernah. Distribusi frekuensi karakteristik responden selengkapnya disajikan pada Tabel 1 .

Gambaran karakteristik responden seperti terlihat pada Tabel 1 terlihat bahwa responden terbanyak adalah di usia muda yaitu $<20$ tahun sebanyak $42,77 \%$ dan kedua terbanyak yaitu berumur antara 20-40 tahun sebanyak 30,72\%. Tingkat pendidikan petugas pengelola limbah di IKH bervariasi dari yang putus sekolah $(4,82 \%)$ sampai dengan sarjana $(19,28 \%)$ dengan tingkat pendidikan petugas terbanyak pada SMA dan SMP dengan nilai sama yaitu $28,31 \%$. Masa kerja sebagai petugas pengelolaa limbah di IKH terbanyak antara 1-3 tahun sebanyak 33,73\% dan yang paling lama bekerja $>5$ tahun sebanyak $26,51 \%$. Penghasilan perbulan responden terbanyak dengan gaji < Rp. 3.000.000,- sebanyak 62,65\% dan pengahasilan >Rp. 10.000.000.- sebanyak $1,20 \%$.

Penilaian tingkat pengetahuan, sikap dan praktik responden terkait pengelolaan limbah di IKH dilakukan dengan memberikan nilai/skor pada setiap variabel. Sebagian besar responden yang berpartisipasi dalam penelitian ini termasuk ke dalam kategori dengan tingkat pengetahuan baik $(85,54 \%)$, sikap yang baik $(90,96 \%)$ dan tingkat praktik baik $(65,06 \%)$. Sikap, pengetahuan dan praktik dikatakan baik apabila nilai skor yang diperoleh melebihi rata ratanya dan sebaliknya untuk sikap yang kurang. Di sisi lain pekerja yang menangani pengelolaan limbah di IKH masih ada yang memiliki pengetahuan yang kurang $(14,46 \%)$, 
Tabel 1. Distribusi karakteristik responden pengelola limbah di IKH.

\begin{tabular}{ccc}
\hline \multicolumn{1}{c}{ Karakteristik } & Jumlah responden $\mathrm{n}=166$ & Persentase (\%) \\
\hline Umur (tahun) & 92 & 42,77 \\
$-\quad<20$ & 31 & 30,72 \\
$-\quad 20-40$ & 36 & 22,29 \\
$-\quad 40-60$ & 7 & 4,22 \\
$-\quad>60$ & & \\
Pendidikan & 8 & 4,82 \\
$-\quad$ Tidak sekolah & 27 & 16,27 \\
$-\quad$ SD & 47 & 28,31 \\
$-\quad$ SMP & 47 & 28,31 \\
$-\quad$ SMA & 5 & 3,01 \\
$-\quad$ Diploma & 32 & 19,28 \\
$-\quad$ Sarjana & & \\
Masa Kerja (tahun) & 20 & 12,05 \\
$-\quad<1$ & 56 & 33,73 \\
$-\quad 1-3$ & 46 & 27,71 \\
$-\quad 3-5$ & 44 & 26,51 \\
$-\quad>5$ & & \\
Penghasilan (perbulan) & 104 & 62,65 \\
$-\quad$ Rp 3 jt & 51 & 30,72 \\
$-\quad$ Rp.3jt- Rp. 5jt & 9 & 5,42 \\
$-\quad$ Rp. >5 Jt-10Jt & 2 & 1,20 \\
\hline
\end{tabular}

Tabel 2. Penilaian tingkat pengetahuan dan sikap terhadap praktik pengelolaan limbah di IKH.

\begin{tabular}{|c|c|c|}
\hline Karakteristik responden & Jumlah $n=166$ & Persentase (\%) \\
\hline \multicolumn{3}{|l|}{ Tingkat Pengetahuan } \\
\hline - $\quad$ Kurang & 24 & 14,46 \\
\hline Baik & 142 & 85,54 \\
\hline \multicolumn{3}{|l|}{ Sikap } \\
\hline Kurang & 15 & 9,03 \\
\hline - Baik & 151 & 90,94 \\
\hline \multicolumn{3}{|l|}{ Tingkat praktik } \\
\hline - $\quad$ Kurang & 58 & 34,94 \\
\hline - Baik & 108 & 65,06 \\
\hline
\end{tabular}

Tabel 3. Persamaan regresi dalam analisis jalur.

\begin{tabular}{cccl}
\hline Model & $\begin{array}{c}\text { Variabel endogen } \\
\text { (tidak bebas) }\end{array}$ & \multicolumn{1}{c}{$\begin{array}{c}\text { Variabel eksogen } \\
\text { (bebas) }\end{array}$} & Persamaan struktur \\
\hline 1 & $\mathrm{P}$ & $\mathrm{X} 1, \mathrm{X} 2, \mathrm{X} 3, \mathrm{X} 4$ & $\mathrm{X} 6=\rho_{\mathrm{x} 6 \mathrm{x} 1} \mathrm{X} 1+\rho_{\mathrm{x} 6 \mathrm{x} 2 \mathrm{X} 2+\rho_{\mathrm{x} 6 \mathrm{x} 3} \mathrm{X} 3+\rho_{\mathrm{x} 6 \mathrm{x} 4} \mathrm{X} 4+\bullet \varepsilon_{\mathrm{x} 6}}$ \\
2 & $\mathrm{~S}$ & $\mathrm{X} 1, \mathrm{X} 2, \mathrm{X} 3, \mathrm{X} 4, \mathrm{P}$ & $\mathrm{X} 7=\rho_{\mathrm{sx} 1} \mathrm{X} 1+\rho_{\mathrm{sx} 2} \mathrm{X} 2+\rho_{\mathrm{sx} 3} \mathrm{X} 3+\rho_{\mathrm{sx} 4} \mathrm{X} 4+\bullet \varepsilon_{\mathrm{s}}$ \\
3 & $\mathrm{Y}$ & $\mathrm{X} 1, \mathrm{X} 2, \mathrm{X} 3, \mathrm{X} 4, \mathrm{P}, \mathrm{S}$ & $\mathrm{Y}=\rho_{\mathrm{yx} 1} \mathrm{X} 1+\rho_{\mathrm{yx} 2} \mathrm{X} 2+\rho_{\mathrm{yx} 3} \mathrm{X} 3+\rho_{\mathrm{yx} 4} \mathrm{X} 4+\rho_{\mathrm{yp}} \mathrm{P}+\rho_{\mathrm{ys}} \mathrm{S}+\bullet \varepsilon_{\mathrm{y}}$ \\
\hline
\end{tabular}

Keterangan: Umur (X1), pendidikan (X2), masa kerja (X3), penghasilan (X4), pengetahuan (P), sikap (S), dan praktik (Y)

Sikap yang buruk $(9,03 \%)$ dan praktik yang buruk $(34,94 \%)$. Penilaian skor pengetahuan, sikap dan praktik pengelolaan limbah di IKH selengkapnya disajikan pada Tabel 2. Tingkat praktik yang cukup penting dinilai dengan kaitan pencegahan penyebaran penyakit yang mungkin terbawa dalam lalu lintas ternak dan pengendalian pencemaran lingkungan seperti pencemaran air, tanah dan udara yang timbul akibat aktivitas di IKH.

Dari hasil analisis terhadap persamaan regresi pada model 1, diketahui $\mathrm{Sig}<0,05$ sehingga $\mathrm{H} 0$ ditolak dan $\mathrm{H} 1$ diterima. Hal ini menunjukkan bahwa variabel karakteristik secara secara simultan berpengaruh terhadap pengetahuan petugas dalam pengelolaan limbah di IKH dengan nilai $\mathrm{R}^{2} \mathrm{x1- \textrm {X } 6}$ yaitu $11,5 \%$ lebih kecil dibandingkan pengaruh variabel lain yaitu $88,5 \%$. Pada model 2 , diketahui $\mathrm{Sig}<0,05$ sehingga $\mathrm{H} 0$ ditolak dan $\mathrm{H} 1$ diterima hal ini menunjukkan bahwa variabel Karakteristik dan pengetahuan mempengaruhi sikap petugas pada pengelolaan limbah di IKH dengan nilai $\mathrm{R}^{2} \mathrm{x1- \textrm {X } 6 , \mathrm { X } 7}$ yaitu $19,3 \%$ maka besarnya pengaruh variabel lain yaitu $80,7 \%$. Hasil analisis pada model 3 diketahui $\mathrm{Sig}<0,05$ sehingga $\mathrm{H} 0$ ditolak dan $\mathrm{H} 1$ diterima hal ini menunjukkan bahwa variabel Karakteristik, pengetahuan dan sikap mempengaruhi praktik petugas dalam pengelolaan limbah di IKH dengan 
nilai $\mathrm{R}^{2} \mathrm{x1- \textrm {x } 6 , \mathrm { X } 7 , \mathrm { x } 8}$ yaitu $26,8 \%$ maka besarnya pengaruh variabel lain yaitu $73,2 \%$.

Hasil analisis jalur, selengkapnya disajikan pada Gambar 2. Variabel yang memberikan pengaruh signifikan dan positif terhadap praktik pengelolaan limbah di IKH adalah tingkat pengetahuan $(\mathrm{r}=0,356 ; 20,62 \%)$. Pengetahuan berpengaruh langsung dan signifikan terhadap praktik menunjukkan bahwa semakin baik tingkat pengetahuan yang dimiliki petugas pengelola limbah di IKH, maka tingkat praktiknya terhadap pencegahan penyebaran penyakit yang mungkin terbawa dalam lalu lintas ternak dan pengendalian pencemaran lingkungan seperti pencemaran air, tanah dan udara yang timbul akibat aktivitas di IKH akan semakin baik pula. Sejalan dengan hasil penelitian Khoiron (2012), bahwa terdapat hubungan yang kuat dan positif antara pengetahuan dengan praktik peternak sapi perah dalam menangani limbah ternaknya.

Pengetahuan peternak tentang sumber, wujud, jenis, sifat, dampak, cara menangani dengan benar, pengolahan, pemanfaatan, dan pemakaian alat pelindung diri, sebagai kumpulan informasi yang dipahami, diperoleh dari proses belajar selama hidup, dapat digunakan sebagai salah satu modal untuk menyesuaikan diri, baik terhadap diri sendiri maupun lingkungannya dengan menangani limbah dengan benar (Khoiron, 2012). Pengetahuan merupakan domain yang sangat penting untuk terbentuknya tindakan seseorang. Tindakan yang didasari oleh pengetahuan akan lebih langgeng daripada tindakan yang tidak didasari oleh pengetahuan (Abidin, 2006). Pengetahuan tentang limbah peternakan dapat diperoleh dari pengalaman, guru, keluarga, teman, petugas penyuluh peternakan, petugas lingkungan hidup, lembaga swadaya masyarakat, perguruan tinggi, media cetak, media elektronik, dan sebagainya (Khoiron, 2012).

Dari hasil penelitian ini juga terlihat bahwa tingkat pengetahuan mempengaruhi sikap secara signifikan dengan nilai koefisien jalur positif $(\mathrm{r}=$ 0,306; 7.95\%). Pengetahuan merupakan predisposisi untuk melakukan tindakan dan menjadi dasar terbentuknya sikap seseorang. Pengetahuan yang terus menerus bertambah menimbulkan perubahan sikap seseorang. Hal tersebut sesuai dengan pernyataan Miftahudin dan Kartinah (2008) juga menyatakan dalam penelitiannya bahwa responden dengan pengetahuan baik memiliki sikap positif terhadap flu burung.

Pengetahuan sendiri dipengaruhi oleh faktor pendidikan formal. Pengetahuan sangat erat hubungannya dengan pendidikan, di mana diharapkan bahwa dengan pendidikan yang tinggi

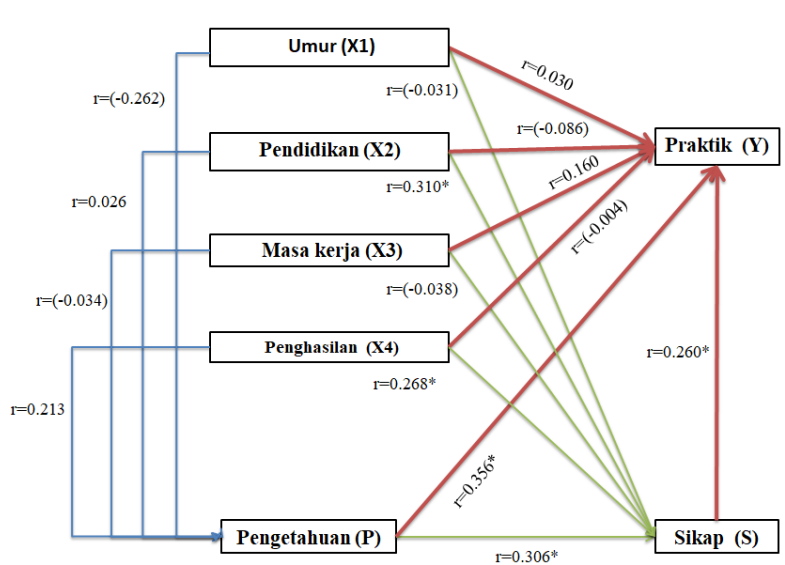

Gambar 2. Hasil analisis jalur variabel karakteristik individu, pengetahuan, sikap terhadap praktik pengelolaan limbah di IKH.

maka orang tersebut akan semakin luas pengetahuannya. Akan tetapi perlu ditekankan bahwa orang yang berpendidikan rendah tidak mutlak berpengetahuan rendah pula. Hal ini mengingatkan bahwa peningkatan pengetahuan tidak mutlak diperoleh dari pendidikan formal saja, tetapi diperoleh dari pendidikan non formal. Semakin tinggi tingkat pengetahuan maka semakin baik sikap seseorang. Karakteristik yang paling mendorong tingkat pengetahuan adalah penghasilan $(\mathrm{r}=0,213 ; 7,5 \%)$.

Menurut Miftahudin dan Kartinah (2008), Pengetahuan yang terus menerus bertambah menimbulkan perubahan sikap seseorang. Hal tersebut sejalan dengan hasil penelitian ini, sikap berpengaruh signifikan terhadap praktik pengelolaan limbah di IKH dengan nilai koefisien jalur positif $(\mathrm{r}=0,260 ; 6,7 \%)$. Karakteristik pendidikan $(\mathrm{r}=0,310)$ dan penghasilan $(\mathrm{r}=0,268)$ mempunyai pengaruh yang signifikan terhadap sikap dibandingkan karakteristik lainnya. Hal yang sejalan dikemukakan oleh Putra dkk., (2013), bahwa tingkat pendidikan dan pendapatan berpengaruh secara positif terhadap sikap keluarga dalam pengelolaan sampah di Desa Condongcatur. Sikap dikatakan sebagai suatu respons evaluatif. Respon hanya akan timbul apabila individu dihadapkan pada suatu stimulus yang menghendaki adanya reaksi individual. Respon evaluatif berarti bahwa bentuk reaksi yang dinyatakan sebagai sikap itu timbul didasari oleh proses evaluasi dalam diri individu yang memberi kesimpulan terhadap stimulus dalam bentuk nilai nilai baik-buruk, positif-negatif, menyenangkan-tidak menyenangkan, yang kemudian mengkristal sebagai potensi reaksi terhadap objek sikap. Perubahan sikap tersebut selanjutnya menimbulkan perubahan perilaku (Fabrigar dkk., 2006). 
Pada penelitian ini, pengetahuan $(r=0,356)$ dan sikap $\quad(r=0,260) \quad$ berpengaruh signifikan menyumbangkan $27,325 \%$ dengan jalur positif terhadap praktik pengelolaan limbah di IKH. Pengetahuan bisa secara langsung mempengaruhi, atau melalui mediasi sikap yang secara tidak langsung mempengaruhi praktik pengelolaan limbah Hal tersebut sejalan dengan penelitian Murharyati (2010) dalam penelitiannya menyatakan bahwa terdapat hubungan yang bermakna antara sikap dan praktik. Semakin baik pengetahuan dan semakin positif sikap seseorang maka semakin baik pula praktik yang dilakukan (Mboe dkk., 2012).

Menurut penelitian Akhtar dan Soetjipto (2014), pengetahuan dan sikap secara bersama sama menyumbangkan $33,3 \%$ dari perubahan variasi dari perilaku meminimisasi sampah. Sikap seseorang dapat berubah karena pengaruh interaksi sosial. Dalam interaksi sosial, terjadi hubungan saling mempengaruhi diantara individu yang satu dengan yang lain. Individu bereaksi membentuk pola sikap tertentu terhadap berbagai objek yang dihadapi dan sikap tersebut dapat mencetuskan perbaikan yang lebih mudah (Armitage dan Conner 2001; Fabrigar dkk. 2006).

Umur mempengaruhi tingkat pengetahuan secara langsung dengan nilai koefisien jalur negatif $(\mathrm{r}=-0,262: 0,09 \%)$. Berdasarkan Tuokko dkk., (2007), seseorang yang lebih muda cenderung lebih terbuka terhadap informasi dan ide-ide baru serta terhadap wawasan pengetahuan yang lebih luas. Hal ini berbeda dengan pendapat Soekanto (2003) bahwa dengan bertambahnya umur maka pengetahuan seseorang akan bertambah. Dalam penelitian ini mayoritas responden adalah berusia muda. Hal yang sama pada penghasilan perbulan yang mempengaruhi tingkat pengetahuan terhadap pengelolaan limbah di IKH secara signifikan dengan nilai koefisien jalur positif $(r=0,232$ : $0,19 \%$ ). Sejalan dengan penelitian Indrianawati dan Soesatyo (2015) yang menyatakan bahwa secara simultan tingkat pendapatan mempunyai pengaruh nyata terhadap tingkat pengetahuan. Ukuran pengaruh setiap variabel yang diteliti diperoleh dari koefisien jalur secara langsung ke praktik maupun tidak langsung melalui variabel lain terlihat pada Tabel 4 dan 5.

Hasil analisis jalur tersebut menunjukkan bahwa total pengaruh seluruh variabel karakteristik, pengetahuan, sikap pengelola limbah IKH terhadap praktik pencegahan penyebaran penyakit yang mungkin terbawa dalam lalu lintas ternak dan pengendalian pencemaran lingkungan seperti pencemaran air, tanah dan udara yang timbul akibat aktivitas di IKH dalam penelitian ini adalah $68,85 \%$, sedangkan $31,15 \%$ dipengaruhi oleh faktor lain yang tidak termasuk dalam penelitian. Dari hasil penelitian ini diperoleh bahwa pengaruh langsung dari karakteristik, pengetahuan dan sikap petugas terhadap praktik pengelolaan limbah di IKH adalah 22,76\% dengan variabel paling berpengaruh adalah tingkat pengetahuan sebesar $12,67 \%$, selanjutnya sikap dengan nilai $6,7, \%$.

Pengaruh tidak langsung terhadap praktik pengelolaan limbah di IKH sebesar 46,09\% dengan variabel terbesar adalah penghasilan $(16,24 \%)$, umur $(12,40 \%)$, dan pendidikan $(12,22 \%)$. Dari hasil penelitian ini, sikap memiliki pengaruh yang

Tabel 4. Nilai koefisien jalur pada pengaruh langsung dan tidak langsung dari variabel yang diamati terhadap praktik pengelolaan limbah di IKH.

\begin{tabular}{|c|c|c|c|c|c|c|c|c|c|c|c|c|}
\hline \multirow[b]{2}{*}{ Variabel } & \multirow[b]{2}{*}{$\begin{array}{l}\text { Pengaruh } \\
\text { langsung }\end{array}$} & \multicolumn{11}{|c|}{ Pengaruh tidak langsung } \\
\hline & & \multicolumn{2}{|c|}{$\begin{array}{c}\text { Melalui } \\
\text { Pengetahuan }\end{array}$} & \multirow{2}{*}{$\begin{array}{c}\text { Jumlah } \\
-0,09327\end{array}$} & \multicolumn{2}{|c|}{ Melalui sikap } & \multirow{2}{*}{$\begin{array}{c}\text { Jumlah } \\
-0,0081\end{array}$} & \multicolumn{3}{|c|}{$\begin{array}{l}\text { Melalui pengetahuan dan } \\
\text { sikap }\end{array}$} & \multirow{2}{*}{$\begin{array}{l}\text { Jumlah } \\
-0,0208447\end{array}$} & \multirow[t]{2}{*}{$\begin{array}{c}\text { Total } \\
\begin{array}{c}\text { Pengaruh } \\
\text { tidak } \\
\text { langsung }\end{array} \\
-0,1221767\end{array}$} \\
\hline Umur & 0,03 & $-0,262$ & 0,356 & & $-0,03$ & 0,26 & & $-0,262$ & 0,306 & 0,26 & & \\
\hline Pendidikan & $-0,086$ & 0,026 & 0,356 & 0,009256 & 0,31 & 0,26 & 0,0806 & 0,026 & 0,306 & 0,26 & 0,00206856 & 0,09192456 \\
\hline Masa Kerja & 0,16 & 0,034 & 0,356 & 0,012104 & $-0,04$ & 0,26 & $-0,0099$ & 0,034 & 0,306 & 0,26 & 0,00270504 & 0,00492904 \\
\hline Penghasilan & 0,004 & 0,213 & 0,356 & 0,075828 & 0,268 & 0,26 & 0,06968 & 0,213 & 0,306 & 0,26 & 0,01694628 & 0,16245428 \\
\hline $\begin{array}{l}\text { Total } \\
\text { Pengetahuan }\end{array}$ & $0,356^{*}$ & & & & & & & & 0,306 & 0,26 & 0,07956 & 0,07956 \\
\hline Total Sikap & $0,260 *$ & & & & & & & & & & & \\
\hline
\end{tabular}

Tabel 5. Ukuran pengaruh variabel penelitian terhadap tingkat praktik pengelolaan limbah di IKH.

\begin{tabular}{lccr}
\hline \multicolumn{1}{c}{ Pengaruh langsung } & Pengaruh langsung (\%) & Pengaruh tidak langsung (\%) & Total pengaruh $(\%)$ \\
\hline Umur & 0,09 & 12,22 & 12,31 \\
Pendidikan & 0,74 & 9,19 & 9,93 \\
Masa kerja & 2,56 & 0,49 & 3,05 \\
Penghasilan & 0,0016 & 16,24 & 16,2416 \\
Total pengetahuan & 12,67 & 7,95 & 20,62 \\
Total sikap & 6,70 & --- & 6,7 \\
Total & 22,76 & 46,09 & 68,85 \\
\hline
\end{tabular}

Keterangan : (*) Signifikan pada P $<0,05$ 
lebih kecil dibanding pengetahuan terhadap praktik pengelolaan limbah di IKH, padahal diketahui diketahui bahwa pengetahuan mempengaruhi perilaku dimediasi melalui sikap. Artinya, sebesar apapun pengetahuan yang dimiliki, jika tidak didukung dengan sikap positif maka pengaruhnya terhadap praktik akan kecil (Akhtar dan Soetjipto, 2014). Oleh karena itu, intervensi untuk meningkatkan praktik pengelolaan limbah di IKH akan lebih efektif jika difokuskan kepada peningkatan sikap terhadap pengelolaan limbah di IKH. Azwar (2011) mengungkapkan pembentukan sikap dipengaruhi oleh beberapa faktor yakni pengalaman pribadi, kebudayaan, orang lain yang dianggap penting, media masa, lembaga pendidikan dan lembaga agama, dan faktor emosional.

Sesuai hasil analisis jalur, maka untuk meningkatkan tingkat praktik pengelolaan limbah di IKH sebagai tindakan pencegahan penyebaran penyakit yang mungkin terbawa dalam lalu lintas ternak dan pengendalian pencemaran lingkungan seperti pencemaran air, tanah dan udara yang timbul akibat aktivitas di IKH, maka intervensi yang dapat dilakukan adalah meningkatkan pengetahuan terhadap semua petugas tanpa membedakan umur mengenai penyakit dan bahaya yang akan timbul akibat pengelolaan limbah IKH yang tidak baik. Hal tersebut dapat dilakukan melalui pelatihan terhadap petugas pengelola limbah di IKH. Semakin meningkatnya pengetahuan. sikap juga diharapkan akan berubah menjadi positif dan akan meningkatkan nilai praktik terhadap pengelolaan limbah di IKH.

Berbagai jenis pelatihan yang telah tersedia saat ini terkait pengelolaan limbah di suatu unit usaha, antara lain pelatihan AMDAL, UKL/UPL dan sistem manajemen lingkungan sesuai ISO 14001:2015. Dalam audit kelayakan IKH oleh Badan Karantina Pertanian, Standar operasional prosedur (SOP) dalam pengelolaan limbah IKH menjadi elemen penting yang harus tersedia dan di nilai oleh auditor dalam penetapan suatu IKH mengingat limbah IKH dapat menjadi media penularan penyakit yang mungkin terbawa bersama dengan lalu lintas ternak. Hanya saja implementasi terhadap SOP tersebut belum sepenuhnya dilakukan secara berkelanjutan mengingat adanya nilai ekonomis dari limbah tersebut. Dengan demikian sangat perlu dilakukan pengawasan terhadap penerapan SOP pengelolaan limbah di IKH.

\section{KESIMPULAN}

Peran karakteristik, pengetahuan dan sikap petugas IKH berpengaruh baik secara langsung dan tidak langsung terhadap praktik pengelolaan limbah di IKH. Umur dan penghasilan berpengaruh signifikan terhadap tingkat pengetahuan. Pengetahuan pekerja berpengaruh signifikan terhadap sikap dan praktik pengelolaan limbah di IKH. Karakteristik, pengetahuan, sikap pengelola limbah IKH terhadap praktik pencegahan pencegahan penyebaran penyakit yang mungkin terbawa dalam lalu lintas ternak dan pengendalian pencemaran lingkungan seperti pencemaran air, tanah dan udara yang timbul akibat aktivitas di IKH adalah $68,85 \%$ sedangkan sisanya, yaitu $31,6 \%$ dipengaruhi oleh faktor lain yang tidak termasuk dalam penelitian. Praktik pengelolaan limbah di IKH dapat ditingkatkan dengan cara meningkatkan pengetahuan melalui pelatihan. Berbagai jenis pelatihan yang telah ada terkait pengelolaan limbah di suatu unit usaha, antara lain pelatihan AMDAL dan UKL/UPL. Perusahaan IKH sepenuhnya telah memilik Standar operasional prosedur dalam pengelolaan limbah IKH yang perlu diimplementasikan dan dievaluasi secara berkelanjutan.

\section{DAFTAR PUSTAKA}

Abidin, Z., 2006. Filsafat Manusia: Memahami Manusia Melalui Filsafat. Ed 5. Bandung: Remaja Rosdakarya.

Anonim, 2008. World Health Organization. Advocacy, Communication and SocialMobilization for TB Control: A Guide to Developing Knowledge, Attitude and Practice Surveys. Geneva: WHO Pr.

Anonim, 2017. Laporan Tahunan Badan Karantina Pertanian. Jakarta.

Akhtar, H., dan Soetjipto, H.P., 2014. Peran Sikap dalam Memediasi Pengaruh Pengetahuan Terhadap Perilaku Minimisasi Sampah Pada Masyarakat Terban, Yogyakarta. J Manusia dan Lingkungan. 21(3):386-392.

Amirin, T., 2011. Populasi dan Sampel Penelitian 4: Ukuran Sampel Rumus Slovin. Jakarta: Erlangga.

Armitage, C.J., dan Conner M., 2001. Efficacy of The Theory of Planned Behaviour: A MetaAnalytic Review. Brazil. J. Soc. Psychol., 40:471-499.

Azwar, S., 2011. Sikap Manusia: Teori dan Pengukurannya Edisi ke-2. Yogyakarta: Pustaka Pelajar.

Fabrigar, L.R., Smith, S.M., Petty, R.E., and Crites, S.L., 2006. Understanding Knowledge Effects on Attitude-Behavior Consistency: The Role of Relevance, Complexity, and Amount of Knowledge. J. Pers. Soc. Psychol., 90(4):556577. 
Hart, M.B., Cathy, M.S., Neumann, M., and Veltri, A.T., 2007. Hand Injury Prevention Training:Assesing Knowledge, Attitude and Behavior. J. SH\&E Research, 3:1-23.

Hutchison, M.L., Walters, L.D., Avery, S.M., Synge, B.A., and Moore, A., 2004. Levels of Zoonotic Agents in British Livestock Manures. Letter in applied Microbiology, 99:58-65.

Idrus, M., 2009. Metode Penelitian Ilmu Sosial. Pendekatan Kualitatif dan Kuantitatif. Ed ke2. Hayati Editor. Jakarta: Erlangga

Indrianawati, E., dan Soesatyo, Y., 2015. Pengaruh Tingkat Pendapatan dan Pengetahuan Ekonomi Terhadap Tingkat Konsumsi Mahasiswa Program Pascasarjana Universitas Negeri Surabaya. Jurnal Ekomomi, Pendidikan dan Kewirausaan. 3(1):214-226.

Keraf, S., 2002. Etika Lingkungan. Jakarta: Penerbit Buku Kompas.

Khoiron, 2012. Perilaku Peternak Sapi Perah dalam Menangani Limbah. Jurnal IKESMA, 8(2):9077.

Mboe, M., Rahayuningsih, S.E., dan Rusmil, K., 2012. Pengetahuan dan Sikap Bidan Dalam Praktik Penyimpanan Vaksin Pada Bidan Praktik Swasta. J. Indones. Med. Assoc. 62(10):402-406.

Miftahudin, A., dan Kartinah, 2008. Hubungan Pengetahuan Tentang Flu Burung dengan Sikap Masyarakat yang Melihara Ungags di Wilayah Mojogedang. Berita Ilmu Keperawatan, 1(4):157-162.

Murharyati, A., 2010. Hubungan Antara Tingkat Pengetahuan dan Sikap Ibu Dengan Praktik Cara Perawatan Balita yang Menderita ISPA
Non Pneumonia di Wilayah Kerja Puskesmas Mojolaban Kab. Sukoharjo. Jurnal Kesehatan Kusuma Husada, 1(1):34-39.

Palaian, S., Acharya, L.D., Rao, P.G.M., Shankar, P.R., and Nair, N.P., 2007. Knowledge, Attitude and Practices Outcomes: Evaluating The Impact of Counseling in Hospitalized Diabetic Patient in India. J. Pharmacol., 7:383-396.

Putra, H. P., Taufiq, A. R., dan Jualiani, A. 2013. Studi Hubungan Antara Tingkat Pendidikan dan Pendapatan Keluarga Terhadap Sikap dalam Pengelolaan Sampah Rumah Tangga (Studi Kasus di Desa Condongcatur, Depok, Sleman, Yogyakarta. Jurnal Sains dan Teknologi Lingkungan, 5(2):91-101.

Samani, M., dan Hariyanto, 2012. Konsep dan Model Pendidikan Karakter. Bandung: PT Remaja Rosdakarya Offset.

Santoso, G., 2012. Kajian Biosekuriti Instalasi Karantina Hewan di Pulau Jawa [tesis]. Bogor: Institut Pertanian Bogor.

Scanes, C.G., 2018. Animal and Human Society. New York: Academic Press.

Soekanto, S., 2003. Sosiologi Suatu Pengantar. Jakarta: UI Press.

Tuokko, H.A., McGee, P., Gabriel, G., and Rhodes, R.E., 2007. Perception, Attitudes and Beliefs, and Openness to Change: Implications for Older Driver Education. Accident Anal. Prev., 39: 812- 817.

Widayati, A. 2012. Health Seeking Behavior di Kalangan Masyarakat Kota Yogyakarta. Jurnal Farmasi, Sains dan Komunitas, 9(2):59-65. 